\title{
INTOLERANCE OF UNCERTAINTY OVER COVID-19 PANDEMIC AND ITS EFFECT ON ANXIETY AND DEPRESSIVE SYMPTOMS do
}

\author{
Macarena Verónica del Valle a \& b 1®iD, María Laura Andrés a \& b ${ }^{\circledR}$, Sebastián

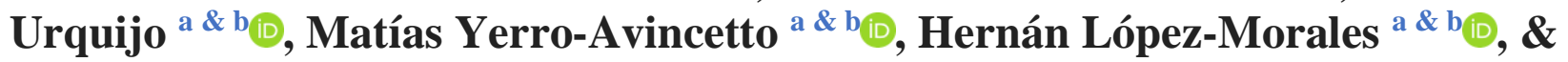 \\ Lorena Canet-Juric ${ }^{\text {a } \& \text { b }}{ }^{2}$ \& 3
}

Consejo Nacional de Ciencia y Técnica, Mar del Plata, Argentina ${ }^{\text {a }}$, Universidad Nacional de Mar del Plata, Mar del Plata, Argentina ${ }^{\text {b. }}{ }^{4}$

\begin{abstract}
The COVID-19 pandemic represents an unprecedented uncertain situation. The aim of this study is to determine the effect of intolerance of uncertainty over COVID-19 pandemic on anxiety and depressive symptoms during quarantine. The study was conducted with 3805 Argentinean participants, who filled the Beck Depression Inventory, the StateTrait Anxiety Inventory, and a modified version of the Intolerance of Uncertainty Scale. Regression analyses indicated a significant effect of intolerance of uncertainty on anxiety and on depressive symptoms. A minor effect of age and gender was also found. Young women with greater intolerance of uncertainty showed the highest levels of anxiety and depressive symptoms. Even though uncertainty distress is an understandable reaction to the current situation, these psychological effects should be monitored.
\end{abstract}

\section{Keywords}

distress; uncertainty; psychological effect; mental health; infectious disease

\section{RESUMEN}

La pandemia del COVID-19 representa una situación incierta sin precedentes. El objetivo del estudio es determinar el efecto de la intolerancia a la incertidumbre generada por la pandemia, sobre los síntomas de ansiedad y depresión durante la cuarentena. Un total de 3805 argentinos completaron el Inventario de Depresión Beck-II, el Inventario Ansiedad Estado-Rasgo y una versión modificada de la Escala de Intolerancia a la Incertidumbre. Las regresiones indicaron un efecto de la intolerancia a la incertidumbre sobre la ansiedad y la depresión. También se encontró un efecto menor del género y la edad. Las mujeres jóvenes con mayor intolerancia a la incertidumbre son quienes muestran mayores síntomas de ansiedad y depresión. Aunque la incertidumbre es una reacción comprensible ante la pandemia, estos efectos psicológicos deben ser monitoreados.

Palabras clave

malestar; incertidumbre; efecto psicológico; salud mental; enfermedad infecciosa

\section{INTOLERANCIA A LA INCERTIDUMBRE GENERADA POR LA PANDEMIA DE}

\footnotetext{
1 Correspondence about this article should be addressed to Macarena del Valle: $\underline{\text { mdelvalle1989@gmail.com }}$

2 Financial support: This research was supported by CONICET (National Scientific and Technical Research Council - Argentina) and by the Program for Federal Articulation and Strengthening of Capacities in Science and Technology COVID-19 (EX-2020-38759422, RI: Canet-Juric; Ministry of Science, Technology and Innovation of the Argentine Nation).

3 be construed as a potential conflict of interest.

4

Instituto de Psicología Básica Aplicada y Tecnología (IPSIBAT), of double dependency.
} 


\section{COVID-19 Y SU EFECTO SOBRE LA ANSIEDAD Y LOS SÍNTOMAS DEPRESIVOS}

\section{Introduction}

On March 20, 2020, with a total of 128 confirmed cases of COVID-19, the Argentine government established a "social, preventive and mandatory isolation" period. Two months later, with millions of confirmed cases worldwide, the outbreak of the COVID-19 has become a global crisis, and, like Argentina, many other countries implement spatial distancing, isolation, and even total quarantine measures to prevent the spread of the virus. These novel living conditions include confinement, loss of freedom, separation from loved ones, changes in routines, transformation of social life, worries about health, financial problems among other consequences for the population (Abbas \& Kamel, 2020; Abel \& McQueen, 2020; Ciacchini, Gemignani, \& Conversano, 2020). And just as it is important to assess the psychological impact of the disease on patients and health care workers, it is equally important to determine the psychological effects on the general population (Sim \& Chua, 2004). Thus, the stress associated with this pandemic implies an overwhelming uncertainty due to the unpredictability of the future and the inability to exert control over what is happening (Zandifar \& Badrfam, 2020).

Uncertainty is a state defined by the presence of vague, complex or unpredictable stimuli or conditions and insufficient or inconsistent information to deal with them (Toro, AvendañoPrieto, \& Vargas 2019). Therefore, uncertainty distress is the subjective and personal negative experience towards different unknown characteristics of events (Freeston, Tiplady, Mawn, Bottesi, \& Thwaites, 2020). Given the current scenario, uncertainty over the COVID-19 pandemic is the inability to determine the course of disease-related events (Kuang \& Wilson, 2017; Mishel, 1988): whether we are already infected or not, whether our relatives and friends will get infected, whether the country's economy will be affected, whether our income will decrease, whether there will be a lack of supplies, etc. The unpredictability of the situation itself is one of the most stressful aspects of the current global pandemic, and, combined with misinformation and biased news, can severely affect mental health (Moreland \& Santacroce, 2018; Satici, Saricali, Satici, \& Griffiths, 2020).

Quarantine is an unpleasant condition that triggers negative emotions such as fear, anger, nervousness, sadness, and boredom (Brooks et al., 2020, Ciacchini et al., 2020). Under current conditions, uncertainty distress is an understandable reaction to an abnormal experience (Freeston 
et al., 2020). However, if threat and uncertainty persist, they can become a problem (Mertens, Gerritsen, Duijndam, Salemink, \& Engelhard, 2020). In this regard, Intolerance of Uncertainty (IU) refers to individual differences in the inability to withstand negative uncertain situations (Buhr \& Dugas, 2002; Carleton, 2016; Freeston, Rhéaume, Letarte, Dugas, \& Ladouceur, 1994; Zvolensky, Vujanovic, Bernstein, \& Leyro, 2010). According to Freeston et al. (2020), the more intolerant to uncertainty a person is, the more he or she will be distressed or upset facing an uncertain situation, regardless of whether the outcome is negative or not. Hence, IU is not only the perception of a threat, but a dispositional tendency to experience uncertainty as aversive and, therefore, react to it with limit tolerance (emotionally, cognitively, or behaviorally; Dugas, Schwartz, \& Francis, 2004; Zvolensky, Leyro, Bernstein, \& Vujanovic, 2011).

Higher levels of IU predispose people to overestimate threats and to find more problems than actually exist (Pepperdine, Lomax, \& Freeston, 2018; Taha, Matheson, Cronin, \& Anisman, 2014). In this sense, the inability to manage the distress arising from uncertain situations (like COVID-19 pandemic) can have a detrimental effect on mental health, leading to different psychopathological symptoms, such as anxiety or depression (Dar, Iqbal, Mushtaq, 2017; Toro et al., 2019). In fact, IU has been highlighted as a transdiagnostic factor for anxiety disorders (Boelen \& Reijntjes, 2009; Carleton, Norton, \& Asmundson, 2007; Carleton et al., 2012; McEvoy \& Mahoney, 2012; Norr et al., 2013) and depressive disorders (Carleton et al., 2012; Mahoney \& McEvoy, 2012; Yook, Kim, Suh, \& Lee, 2010). It is important to emphasize that anxiety and depressive symptoms tend to differ according to gender and age. Women are more likely than men to show anxiety (e.g., Leach, Christensen, Mackinnon, Windsor, \& Butterworth, 2008; McLean, Asnaani, Litz, \& Hofmann, 2011) and depressive symptoms (e.g., Van de Velde, Bracke, \& Levecque, 2010); and young adults are more likely than older ones to experience anxiety (e.g., Goldberg, Breckenridge, \& Sheikh, 2003) and depressive symptoms (e.g., Nolen-Hoeksema \& Aldao, 2011) as well. Also, IU tends to differ according to gender and age, being more pronounced in women than in men (e.g., Dugas et al., 2004; Sexton \& Dugas, 2009), and in young people than in older people (e.g., Basevitz, Pushkar, Chaikelson, Conway, \& Dalton, 2008; Mertens et al., 2020). However, other studies were unable to replicate these findings about gender and age differences in IU (e.g., Carleton et al., 2007; Rodríguez de Behrends \& Brenlla, 2015; Tolin, Abramowitz, Brigidi, \& Foa, 2003). 
Currently, COVID-19 represents an unprecedented uncertain situation. Recently, Satici et al. (2020) conducted a study on the COVID-19 situation and reported that general IU had a significant direct effect on mental wellbeing. Hence, it is possible that individual differences in IU over COVID-19 pandemic may lead to increased psychopathological symptoms (i.e. anxiety and depression) during isolation. At the moment, this issue has not yet been explored. Therefore, the aim of this study is to determine the effect of IU over COVID-19 pandemic on anxiety and depressive symptoms.

\section{Method}

\section{Participants}

The study was conducted with 3805 participants from different cities of Argentina. The age ranged from 18 to 83 years $($ mean $=38.16 ; S D=12.93)$. The inclusion criteria were to be over 18 years old, to live in Argentina, and not to suffer from any serious physical/psychological diseases. Eighty two percent of participants identified themselves as female $(n=3126)$ and $17.8 \%$ identified themselves as male $(n=679)$. Out of the $3805,92.2 \%(n=3508)$ of the participants indicated that they complied with quarantine measures, while $7.8 \%(n=297)$ indicated that they were exempt from quarantine because they work in basic services and activities (e.g., health-care workers, journalists, food businesses). Regarding educational level, $0.1 \%(n=4)$ had completed primary education, $0.7 \%(n=28)$ had incomplete secondary education, 4.7\% $(n=180)$ had completed secondary education, $29.6 \%(n=1127)$ had incomplete or ongoing university or tertiary education, $35.8 \%(n=1363)$ had completed university education, and 29\% $(n=1103)$ had completed or incomplete postgraduate education.

\section{Measures}

Intolerance of uncertainty: a selection of items was made based on the Argentinian adaptation (Rodríguez de Behrends \& Brenlla, 2015) of the Intolerance of Uncertainty Scale (IUS, Freeston et al., 1994). The IUS is a self-administered scale of 27 items that evaluates people's dislike of uncertain situations, such as "Uncertainty makes life intolerable" or "Unforeseen events upset me greatly". Items are rated on a 5-point Likert scale, from 1 (Not at all characteristic of me) to 5 (Very characteristic of me). The scale has two dimensions; the first one is related to the 
Inhibition (cognitive, behavioral, and affective) generated by uncertainty; the second one assesses the Subjective distress generated by uncertainty and unpredictability. Given the aforementioned objectives of this study, modifications were made to the instructions and the items, in order to shorten the scale and specifically asses the uncertainty over the current pandemic. Three expert researchers were consulted for item cutting, indicating those items that (a) were most relevant in the context of isolation, (b) were easier (for different educational levels), (c) most clearly represented what the authors intended to investigate. The same three expert researchers judged the items and instructions modifications. Of the 27 items, 16 were selected as the most appropriate ones and an additional one was elaborated ("It bothers me not being able to control what is going to happen"). The instructions were modified to specify that the person should respond to his or her feelings during the quarantine. Thus, some items originally formulated in present tense (e.g., "uncertainty keeps me from sleeping soundly") were rephrased into past tense ("uncertainty has prevented me from sleeping soundly"). Finally, seven items that assess uncertainty in a general way (e.g., "it's unfair not having any guarantees in life") were slightly modified to reflect the uncertainty over the coronavirus situation ("it's unfair not having guarantees about this situation"). The final scale consisted of 17 items, on which preliminary validity and reliability analyses were performed.

Depression symptoms: The Spanish adaptation (Sanz, García-Vera, Espinosa, Fortún, \& Vázquez, 2005; Sánz \& Vázquez, 2011) of the Beck Depression Inventory-II (BDI-II; Beck, Steer, \& Brown, 1996) was used. The BDI-II is a self-report inventory that assesses the presence and severity of depressive symptoms. It consists of 21 items that indicate symptoms such as sadness, crying, loss of pleasure, guilt, pessimism, etc. In every item, the respondents are asked to choose the statement that best describes their feelings during the past two weeks, including the present day, to be consistent with the DSM-IV criteria for major depression. Each item is answered on a 4-point scale, which describes increasing levels of severity of that symptom. It has adequate reliability ( $\alpha=.89$, Sanz, Perdigón, \& Vázquez, 2003) and validity (e.g. Beltrán, Freyre, \& Hernández-Guzmán, 2012; Sanz \& Vázquez, 1998). Item 9 (suicidal ideation indicator) was omitted for this study due to the potential risk it might imply for online surveys.

State Anxiety: The state anxiety dimension of the Spanish version (Spielberger, Gorsuch, Lushene, \& Cubero, 1999) of the State-Trait Anxiety Inventory (STAI; Spielberger, Gorsuch, Lushene, 1970) was used. The STAI is a self-report instrument composed of 40 items designed to 
separately assess anxiety as a state (transitory condition) and anxiety as a trait (stable condition). For this study, only the state anxiety dimension was applied, which is compound by 20 items that are answered in a range from 0 to 3 . In the Spanish population, the levels of internal consistency of the instrument oscillate from $\alpha .84$ to .93 (Guillén-Riquelme \& Buela-Casal, 2011).

Socio-demographic features: Closed-ended questions on compliance with mandatory isolation, age, and gender were included.

\section{Procedure and ethical considerations}

The survey was elaborated through Google Forms and disseminated through social networks. Participants answered it between May 7 and 17, 2020 (i.e. between 48 and 58 days after the mandatory quarantine was installed in Argentina). For the implementation of this research, all procedures recommended by the Declaration of Helsinki and the American Psychological Association (2010) were met. Participants answer voluntarily and only after signing (digitally) an informed consent form. Contact information of the research group was provided to clarify doubts that may arise concerning the protection of rights in research contexts. The study was approved by the Bioethics Committee of the National University of Mar del Plata.

\section{Data analysis}

Due to the modifications introduced to the original version of the IUS, preliminary analyses about validity and reliability were carried out. The total scale score was calculated and Pearson's $r$ correlations were applied to each item (item-total correlation, Wieland, Durach, Kembro, \& Treiblmaier, 2017). The factor structure of IUS was analyzed by Exploratory Factor Analysis (EFA). Its applicability was considered through the Kaiser-Meyer-Olkin statistic and Bartlett's sphericity test. The EFA was performed through the FACTOR software (v. 10.10.01, LorenzoSeva \& Ferrando, 2019). First, the number of factors was determined through a parallel analysis with optimal implementation (Timmerman \& Lorenzo-Seva, 2011) based on the polychoric correlation matrix. The extraction method was Unweighted Least Squares (ULS), robust against ordinal variables (Lloret-Segura, Ferreres-Traver, Hernández- Baeza, \& Tomás-Marco, 2014). As it revealed a single factor structure, no matrix rotation was performed. The internal consistency of the scale was evaluated using Cronbach's alpha $(\alpha)$.

Before to the association analyses, the normality of the depression, anxiety, and IU was considered through skewness and kurtosis statistics. While IU $(S k=-0.06 ; K u=-0.37)$ and anxiety 
$(S k=0.42 ; K u=-0.20)$ presented acceptable values, depressive symptoms $(S k=1.41 ; K u=2.57)$ showed a leptokurtic distribution with positive skewness. Therefore, the depression variable was normalized through its natural logarithm (Sedgwick, 2012). The resulting skewness and kurtosis $(S k=-0.60 ; K u=0.05)$ showed acceptable values (descriptive statistics of depression were explore with the non-normalized variable; inferential analyses were performed with the normalized variable). Descriptive statistics were calculated for the entire sample. Also, the effect of gender was considered using Student $t$-tests (Cohen's $d$ for effect size; $1-\beta$ for Power), and the effect of age was evaluated using Pearson's $r$ correlations.

Once the preliminary analyses were completed, partial correlations (controlled for gender and age) were performed between anxiety, depression, and IU. Then, two multiple linear regression models were tested (enter method). In both models, gender, age, and IU were the independent variables. The first model assesses the effect of IU over depression, and the second model assesses the effect of IU over anxiety. Collinearity diagnostics showed VIF values lower than 1.02. Residues of both models showed a normal distribution (Model 1: $S k=-0.58 ; K u=0.88$; Model 2: $S k=0.18 ; K u=0.46$ ), and Scatterplots showed homoscedasticity for both models as well. The effect of the independent variables was estimated using standardized $\beta$. Effect size of the regression models was estimated using $f^{2}$, and $\mathrm{G}^{*}$ Power was also considered (Cárdenas Castro \& Arancibia Martini, 2014; Faul, Erdfelder, Buchner, \& Lang, 2009).

Finally, we performed two factorial ANOVAs to explore interaction effects between the independent variables (gender, age, IU) over anxiety and depressive symptoms. Age was recoded into three groups following the World Health Organization criteria (18-24; 25-59; 60 or more; WHO, 2014). IU was recoded into three groups: low IU (Z-score < -1), normal IU (Z-score between -1 and 1), and high IU (Z-score > 1). It is important to highlight that the Levene test was statistically significant for the ANOVAs performed. However, we continue with the analysis, since the ANOVA statistic is sufficiently robust, even against the non-compliance of some of its assumptions, especially in large samples (e.g., Blanca, Alarcón, Arnau, Bono, \& Bendayan, 2017). 


\section{Results}

\section{Preliminary analyses}

Item-total correlations on IUS showed that all items had statistically significant correlations, each greater than $r .49$. The applicability of EFA was evaluated with adequate results $\left(\right.$ Bartlett's $\left._{(136)}=44042.7 ; p<.01 ; \mathrm{KMO}=.95\right)$. The EFA showed a single factor solution, which explained $53.6 \%$ of the variance. Factor loads ranged from .46 to .84 points $($ mean $=.71)$. The $\alpha$ obtained for the scale was .93 .

To determine if there was an effect of gender and age on emotional variables, Student $t$ and Pearson $r$ tests were applied. The $t$-tests (Table 1) showed higher levels of depression, anxiety, and IU in women, with small effect sizes. Concerning age, inverse low correlations $(p<.01)$ were found between the age of the participant and anxiety $(r=-.19 ; p=.01)$, depressive symptoms $(r=$ $-.28 ; p=.01)$, and IU $(r=-.12 ; p=.01)$.

Table 1

Gender differences in levels of anxiety, depression, and IU

\begin{tabular}{lcccccccc}
\hline & \multicolumn{2}{c}{ Female } & \multicolumn{2}{c}{ Male } & \multirow{2}{*}{$t$} & \multirow{2}{*}{$d$} & $1-\beta$ \\
\cline { 2 - 6 } & ME & SD & ME & SD & & & \\
\hline Depression & 2.24 & 0.82 & 1.95 & 0.90 & $8.20^{* *}$ & 0.34 & .999 \\
Anxiety & 23.51 & 10.52 & 20.68 & 9.95 & $6.40^{* *}$ & 0.28 & .999 \\
Intolerance of uncertainty & 50.27 & 13.20 & 46.95 & 13.38 & $5.93^{* *}$ & 0.25 & .997 \\
\hline
\end{tabular}

$* * p<.01$

\section{Associations between emotional variables}

Partial correlations are presented in Table 2. Statistical analyses for all sample were also calculated and are presented in Table 2 as well. Results showed significant large correlations among the variable under study. 
Table 2

Descriptive statistics and correlations between variables

\begin{tabular}{lcccc}
\hline & Depression & Anxiety & ME & SD \\
\hline Depression & - & - & 11.02 & 8.94 \\
Anxiety & $.727^{* *}$ & - & 23.00 & 10.47 \\
Intolerance of uncertainty & $.607^{* *}$ & $.734 * *$ & 49.68 & 13.29 \\
\hline
\end{tabular}

$* * p<.01$

Regression analyses are presented in Table 3. A significant effect of IU on anxiety and on depressive symptoms was observed. The variance explained was larger for anxiety than for depressive symptoms. Thus, the more the IU over the pandemic, the higher the anxiety and the depression. A minor effect of age and gender was also found, although the $\beta$ coefficients were low and, for gender, close to zero. The effect size and the power of both models were very large, although it was larger for anxiety levels.

Table 3

Multiple linear regression with anxiety and depressive symptoms as dependent variables

\begin{tabular}{lcc}
\hline & Anxiety & Depression \\
& $\beta$ & $\beta$ \\
\hline Intolerance of uncertainty & $.73^{* *}$ & $.58^{* *}$ \\
Age & $-.10^{* *}$ & $-.21^{* *}$ \\
Gender & $-.03^{*}$ & $-.06^{* *}$ \\
\hline$r^{2}$ & .56 & .43 \\
\hline $1-\beta$ & 1.00 & 1.00 \\
\hline$f^{2}$ & 1.27 & .75 \\
\hline $\mathrm{F}_{(3,3801)}$ & $1603.04 * *$ & $951.99 * *$ \\
\hline
\end{tabular}

Finally, two factorial ANOVAs were performed to explore interaction effects between the independent variables (gender, age, IU) over anxiety and depressive symptoms. About anxiety ( $F$ $\left.=172.427 ; p<.01 ; \eta_{p}{ }^{2}=.436\right)$, although there were effects of gender $\left(F=6.351 ; p<.01 ; \eta_{p}{ }^{2}=\right.$ $.002)$, age $\left(F=16.550 ; p<.01 ; \eta_{p}{ }^{2}=.009\right)$, and IU $\left(F=259.210 ; p<.01 ; \eta_{p}{ }^{2}=.120\right)$ separately, there were no interaction effects. Similarly, in depression $\left(F=105.847 ; p<.01 ; \eta_{p}{ }^{2}=.322\right)$, there 
were effects of gender $\left(F=7.112 ; p<.01 ; \eta_{p}{ }^{2}=.002\right)$, age $\left(F=41.492 ; p<.01 ; \eta_{p}{ }^{2}=.021\right)$ and IU $\left(F=175.384 ; p<.01 ; \eta_{p}^{2}=.085\right)$, but no interaction effects. The results are presented in Figure 1.

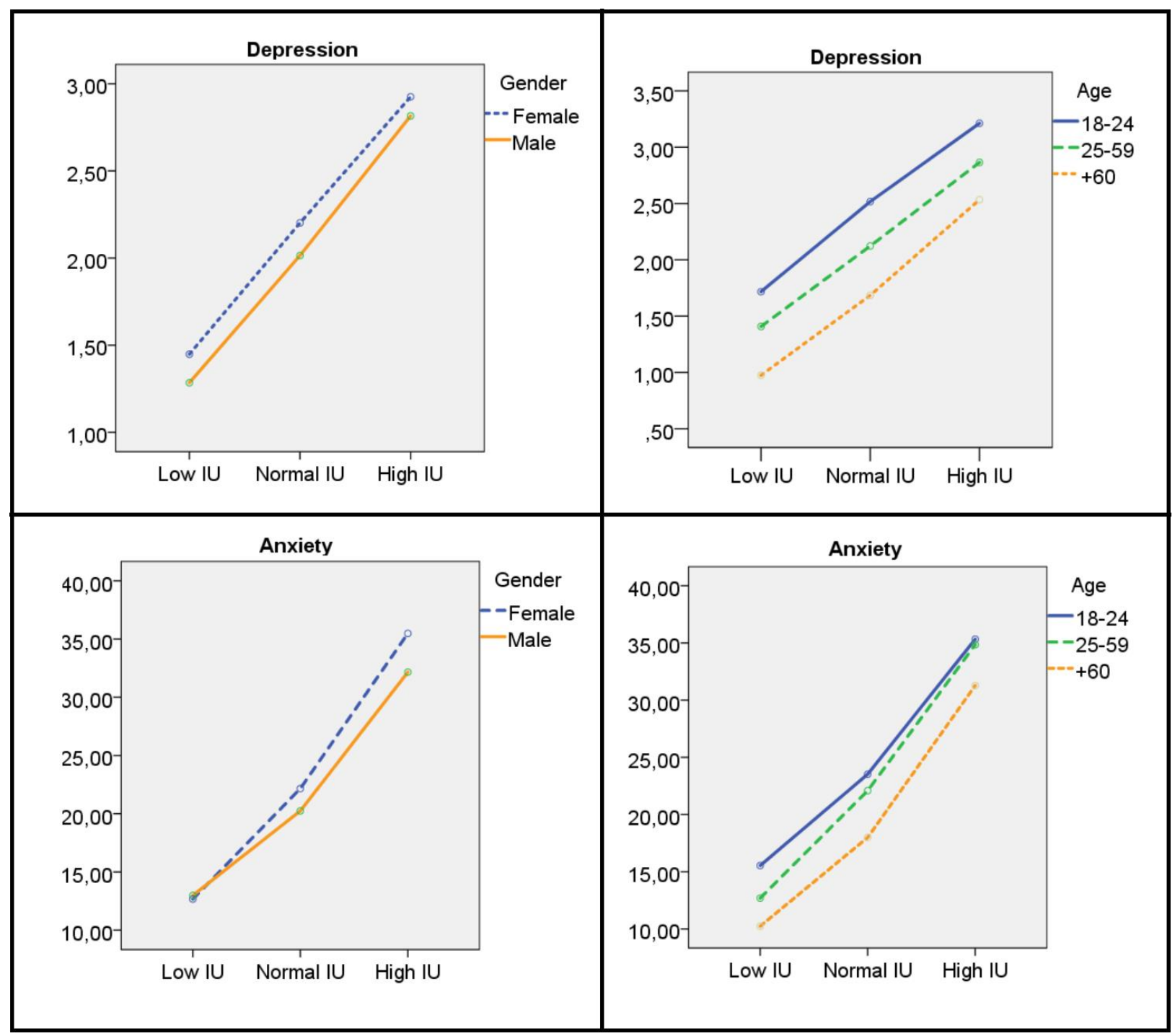

Figure 1. Estimated mean for anxiety and depressive symptoms (interaction of dependent variables). Note: IU = Intolerance of Uncertainty

\section{Discussion}

The COVID-19 pandemic represents an unprecedented challenge, so uncertainty distress is an evident and understandable reaction (Freeston et al., 2020). In this context, distress should not be pathologized, but supported and intervened so it does not lead to more serious problems. Our results indicate that IU over COVID-19 plays a fundamental role in the psychopathological symptoms of the population during confinement. This is consistent with what was reported by 
Satici et al. (2020), who found that IU had a significant direct effect on mental wellbeing during the COVID-19 pandemic. As Brooks et al. (2020) have pointed out, information is the key, so it is essential that people understand what is happening. Otherwise, the perceived distress may lead to over-engagement behaviors (e.g., breaking quarantine), aimed at trying to regain control and certainty over the situation and alleviate the distress (Freeston et al., 2020).

Few conclusions can be drawn from the data collected here about whether levels of anxiety and depression are higher than pre-pandemic measures. Regarding STAI, there are no Argentinean adaptation of the scale and no paper has explored its psychometric properties in our country. Although there are some previous studies in Argentina that have used the STAI, they focus on specific populations (e.g., clinical patients, university students; Biglieri \& Vetere, 2010; Goncalves Mo \& Rodríguez De Behrends, 2015), and generally work with a more limited number of participants (e.g., 200, 300). Similarly, the Argentinian adaptation of the BDI-II in general population (Brenlla \& Rodríguez, 2006) was carried out on a sample of 472 people, all of whom resided in the city of Buenos Aires (our sample included a larger number of participants, who also came from different Argentinean cities). A pre-pandemic measure could have been very enlightening in this matter, and would have allowed us to make valuable comparisons. However, the few published studies on mental health during the COVID-19 pandemic in other countries, have reported increases in the levels of anxiety and depression (Galindo-Vázquez et al., 2020; Ozamiz-Etxebarria, Dosil-Santamaria, Picaza-Gorrochategui, \& Idoiaga-Mondragon, 2020). Also, previous studies have reported a negative psychological effect on the population due to the outbreak of other infectious diseases (Brooks et al., 2020; Mihashi et al., 2009). These studies highlight the importance of addressing both physical and mental health in this uncertain context.

Findings are also aligned with previous studies (out of isolation periods) that point out the importance of IU as a transdiagnostic factor for different psychopathological disorders (Carleton et al., 2007; Katz, Rector, \& Laposa, 2017; McEvoy \& Mahoney, 2012; Norr et al., 2013; Toro et al., 2019). In this regard, Carleton et al. (2012) suggest that transdiagnostic approaches to psychological disorders consider underlying mechanisms across diagnostic categories and that IU represents a fundamental vulnerability for anxiety and depression. Moreover, the more intolerant a person is, the more their cognitions and emotions will be affected when he or she is exposed to uncertain situations (Dugas et al., 2004). 
Nevertheless, previous studies usually report moderate relationships between the variables explored here. State anxiety and IU usually show relations that vary from .37 to .55 points (González, Ibáñez, Rovella, López, \& Padilla, 2013; Rodríguez De Behrends \& Brenlla, 2015; Toro, Alzate, Santana, \& Ramírez, 2018), and depression and IU relations ranged from .34 to .53 points (González et al., 2013; Toro et al., 2018). In contrast, the relationships found in this study between IU (over pandemic) and levels of anxiety and depression were significantly higher, indicating, at least exploratory, the importance of IU in this context.

Regarding age and gender, our results show that there is indeed an effect of these variables over anxiety, depression, and IU, although the effect is clearer for anxiety and depression, which is consistent with previous studies (e.g., Goldberg et al., 2003; McLean et al., 2011; NolenHoeksema \& Aldao, 2011; Van de Velde et al., 2010). The effect size was smaller for IU, which may explain why some studies have found these differences (e.g., Dugas et al., 2004; Mertens et al., 2020; Sexton \& Dugas, 2009), while other researchers have not (e.g, Rodríguez de Behrends \& Brenlla, 2015; Tolin et al., 2003).

Despite the evidence, some limitations should be considered. First, the sample used in the study, while large, was not probabilistic, so many findings cannot be generalized. In fact, a large proportion of people with university degrees (or even postgraduate) participated in the study, which does not represent the distribution of educational level in Argentina. Future studies should consider reaching lower-income social sectors to explore the psychological effects of the COVID-19 pandemic on this population. Also, the present study used self-report measures and was correlational in nature, so further research is needed to investigate IU through behavioral assessment tools (Ameral, Palm Reed, Cameron, \& Armstrong, 2014). Also, other distress tolerance aspects should be considered, such as tolerance of negative emotion, tolerance of frustration, or tolerance of ambiguity (Zvolensky et al., 2010).

In summary, health is an integrative construct, so the psychological effects of quarantine should be taken into account. Uncertainty, anxiety, depressive symptoms, distress, are normal consequences in a pandemic time, but maintaining good mental health is essential (Peitl, Zatezalo, \& Karlović, 2020) to avoid long-term problems (e.g., post-traumatic stress, Brooks et al., 2020) or challenges. In this matter, psychological intervention represents an efficient way to explore potential maladaptive responses as well as to promote psychological support during the COVID-19 pandemic (Ciacchini et al., 2020). 


\section{References}

Abbas, A. M., \& Kamel, M. M. (2020). Dietary habits in adults during quarantine in the context of COVID-19 pandemic, Obesity Medicine, https://doi.org/10.1016/j.obmed.2020.100254

Abel, T., \& McQueen, D. (2020). The COVID-19 pandemic calls for spatial distancing and social closeness: not for social distancing! International Journal of Public Health, 65, 231. https://doi.org/10.1007/s00038-020-01366-7

Ameral, V., Palm Reed, K. M., Cameron, A., \& Armstrong, J. L. (2014). What are measures of distress tolerance really capturing? A mixed methods analysis. Psychology of Consciousness: Theory, Research, and Practice, 1(4), 1-3. https://doi.org/10.1037/cns0000024

American Psychological Association (2010). Ethical principles of psychologists and code of conduct. Autor. http://www.apa.org/ethics/code/principles.pdf

Basevitz, P., Pushkar, D., Chaikelson, J., Conway, M., \& Dalton, C. (2008). Age-related differences in worry and related processes. The International Journal of Aging and Human Development, 66(4), 283-305. https://doi.org/10.2190/AG.66.4.b

Beck, A. T., Steer, R. A., \& Brown, G. K. (1996). Beck depression inventory-II. The Psychological Corporation.

Beltrán, M. C., Freyre, M. Á., \& Hernández-Guzmán, L. (2012). El Inventario de Depresión de Beck: Su validez en población adolescente. Terapia Psicológica, 30(1), 5-13. https://doi.org/10.4067/S0718-48082012000100001

Biglieri, R. R., \& Vetere, G. L. (2010). Ansiedad rasgo y creencias relacionadas con trastornos de ansiedad: Una comparación entre el trastorno de ansiedad generalizada y otros cuadros de ansiedad. Perspectivas en Psicología, 7(1), 8-15. https://www.redalyc.org/pdf/4835/483555653002.pdf

Blanca, M. J., Alarcón, R., Arnau, J., Bono, R., \& Bendayan, R. (2017). Non-normal data: Is ANOVA still a valid option?. Psicothema, 29(4), 552-557. https://doi.org/10.7334/psicothema2016.383

Boelen, P. A., \& Reijntjes, A. (2009). Intolerance of uncertainty and social anxiety. Journal of Anxiety Disorders, 23(1), 130-135. https://doi.org/10.1016/j.janxdis.2008.04.007

Brenlla, M. L., \& Rodríguez, C. M. (2006). Adaptación argentina del Inventario de Depresión de Beck (BDI-II). Buenos Aires: Paidós.

Brooks, S. K., Webster, R. K., Smith, L. E., Woodland, L., Wessely, S., Greenberg, N., \& Rubin, G. J. (2020). The psychological impact of quarantine and how to reduce it: rapid review of the evidence. The Lancet, 395, 912-920. https://doi.org/10.1016/S0140-6736(20)30460-8

Buhr, K., \& Dugas, M.J. (2002). The intolerance of uncertainty scale: Psychometric properties of the English version. Behaviour Research and Therapy, 40(8), 931-945. https://doi.org/10.1016/S0005-7967(01)00092-4

Cárdenas Castro, M., \& Arancibia Martini, H. (2014). Potencia estadística y cálculo del tamaño del efecto en $\mathrm{G}^{*}$ Power: complementos a las pruebas de significación estadística y su aplicación en psicología. Salud \& Sociedad, 5(2), 210-244. https://doi.org/10.22199/s07187475.2014.0002.00006

Carleton, R. N. (2016). Into the unknown: a review and synthesis of contemporary models involving uncertainty. Journal of Anxiety Disorders, 39, 30-43. https://doi.org/10.1016/j.janxdis.2016.02.007 
Carleton, R. N., Mulvogue, M. K., Thibodeau, M. A., McCabe, R. E., Antony, M. M., \& Asmundson, G. J. G. (2012). Increasingly certain about uncertainty: Intolerance of uncertainty across anxiety and depression. Journal of Anxiety Disorders, 26(3), 468-479. https://doi.org/10.1016/j.janxdis.2012.01.011

Carleton, R. N., Norton, M. P. J., \& Asmundson, G. J. (2007). Fearing the unknown: A short version of the Intolerance of Uncertainty Scale. Journal of Anxiety Disorders, 21(1), 105117. https://doi.org/10.1016/j.janxdis.2006.03.014

Ciacchini, R., Gemignani, A., \& Conversano, C. (2020). Psychological intervention measures during the COVID-19 pandemic. April. https://doi.org/10.36131/CN20200208

Dar, K.A., Iqbal, N., Mushtaq, A. (2017). Intolerance of uncertainty, depression, and anxiety: examining the indirect and moderating effects of worry. Asian Journal of Psychiatry, 29, 129-133. https://doi.org/10.1016/j.ajp.2017.04.017

Dugas, M. J., Schwartz, A., \& Francis, K. (2004). Intolerance of uncertainty, worry, and depression. Cognitive Therapy and Research, 28, 835-842. https://doi.org/10.1007/s10608-004-0669-0

Faul, F., Erdfelder, E., Buchner, A., \& Lang, A. G. (2009). Statistical power analyses using G*Power 3.1: Tests for correlation and regression analyses. Behavior Research Methods, 41, 1149-1160. https://doi.org/10.3758/BRM.41.4.1149

Freeston, M. H., Rhéaume, J., Letarte, H., Dugas, M. J., \& Ladouceur, R. (1994). Why do people worry? Personality and Individual Differences, 17(6), 791-802. https://doi.org/10.1016/0191-8869(94)90048-5

Freeston, M., Tiplady, A., Mawn, L., Bottesi, G., \& Thwaites, S. (2020) Towards a model of uncertainty distress in the context of Coronavirus (Covid-19). http://doi.org/10.31234/OSF.IO/V8Q6M

Galindo-Vázquez, O., Ramírez-Orozco, M., Costas-Muñiz, R., Mendoza-Contreras, L. A., Calderillo-Ruíz, G., \& Meneses-García, A. (2020). Síntomas de ansiedad, depresión y conductas de autocuidado durante la pandemia de COVID-19 en la población general. Gaceta Médica, 156, 298-305. https://doi.org/10.24875/GMM.20000266

Goldberg, J. H., Breckenridge, J. N., \& Sheikh, J. I. (2003). Age differences in symptoms of depression and anxiety: examining behavioral medicine outpatients. Journal of Behavioral Medicine, 26(2), 119-132. https://doi.org/10.1023/a:1023030605390

Goncalves Mo, Y., \& Rodríguez De Behrends, M. (2015). Diferencias entre hombres y mujeres en la evaluación de la ansiedad en población Argentina. In VII Congreso Internacional de Investigación y Práctica Profesional en Psicología and XXII Jornadas de Investigación XI Encuentro de Investigadores en Psicología del MERCOSUR. Universidad de Buenos Aires, Buenos Aires. https://www.aacademica.org/000-015/935

González, M., Ibáñez, I., Rovella, A., López, M., \& Padilla, L. (2013). Perfeccionismo e intolerancia a la incertidumbre: relaciones con variables psicopatológicas. Psicología Conductual, 21(1), 81-101. https://psycnet.apa.org/record/2013-17396-005

Guillén-Riquelme, A., \& Buela-Casal, G. (2011). Actualización psicométrica y funcionamiento diferencial de los ítems en el State Trait Anxiety Inventory (STAI). Psicothema, 23(3), 510-515. http://www.psicothema.com/pdf/3916.pdf

Katz, D., Rector, N. A., \& Laposa, J. M. (2017). The interaction of distress tolerance and intolerance of uncertainty in the prediction of symptom reduction across CBT for social anxiety disorder. Cognitive Behaviour Therapy, 46(6), 459-477. https://doi.org/10.1080/16506073.2017.1334087 
Kuang, K., \& Wilson, S. R. (2017). A Meta-Analysis of Uncertainty and Information Management in Illness Contexts. Journal of Communication, 67(3), 378401. https://doi.org/10.1111/jcom.12299

Leach, L. S., Christensen, H., Mackinnon, A. J., Windsor, T. D., \& Butterworth, P. (2008). Gender differences in depression and anxiety across the adult lifespan: the role of psychosocial mediators. Social Psychiatry and Psychiatric Epidemiology, 43(12), 983-998. http://doi.org/10.1007/s00127-008-0388-z

Lloret-Segura, S., Ferreres-Traver, A., Hernández- Baeza, A., \& Tomás-Marco, I. (2014). El análisis factorial exploratorio de los ítems: una guía práctica, revisada y actualizada. Anales de psicología, 30(3), 1151-1169. https://doi.org/10.6018/analesps.30.3.199361

Lorenzo-Seva, U., \& Ferrando, P. J. (2019). Factor Analysis (Versión 10.10.01) [Software]. https://psico.fcep.urv.cat/utilitats/factor

Mahoney, A.0 E., \& McEvoy, P. M. (2012). A transdiagnostic examination of intolerance of uncertainty across anxiety and depressive disorders. Cognitive Behaviour Therapy, 41(3), 212-222. https://doi.org/10.1080/16506073.2011.622130

McEvoy, P. M., \& Mahoney, A. E. (2012). To be sure, to be sure: Intolerance of uncertainty mediates symptoms of various anxiety disorders and depression. Behavior Therapy, 43(3), 533-545. https://doi.org/10.1016/j.beth.2011.02.007

McLean, C. P., Asnaani, A., Litz, B. T., \& Hofmann, S. G. (2011). Gender differences in anxiety disorders: Prevalence, course of illness, comorbidity and burden of illness. Journal of Psychiatric Research, 45(8), 1027-1035. http://doi.org/10.1016/j.jpsychires.2011.03.006

Mertens, G., Gerritsen, L., Duijndam, S., Salemink, E., \& Engelhard, I. M. (2020). Fear of the coronavirus (COVID-19): Predictors in an online study conducted in March 2020. March. https://doi.org/10.31234/osf.io/2p57j

Mihashi, M., Otsubo, Y., Yinjuan, X., Nagatomi, K., Hoshiko, M., \& Ishitake, T. (2009). Predictive factors of psychological disorder development during recovery following SARS outbreak. Health Psychology, 28(1), 91-100. https://doi.org/10.1037/a0013674

Mishel, M. H. (1988). Uncertainty in illness. The Journal of Nursing Scholarship, 20(4), 225-232. https://doi.org/10.1111/j.1547-5069.1988.tb00082.x

Moreland, P., \& Santacroce, S. J. (2018). Illness uncertainty and posttraumatic stress in young adults with congenital heart disease. The Journal of Cardiovascular Nursing, 33(4), 356362. https://doi.org/10.1097/JCN.0000000000000471

Nolen-Hoeksema, S., \& Aldao, A. (2011). Gender and age differences in emotion regulation strategies and their relationship to depressive symptoms. Personality and Individual Differences, 51(6), 704-708. https://doi.org/10.1016/j.paid.2011.06.012

Norr, A. M., Oglesby, M. E., Capron, D. W., Raines, A. M., Korte, K. J., \& Schmidt, N. B. (2013). Evaluating the unique contribution of intolerance relative to other cognitive vulnerability factors in of uncertainty anxiety psychopathology. Journal of Affective Disorders, 151(1), 136-142. https://doi.org/10.1016/j.jad.2013.05.063

Ozamiz-Etxebarria, N., Dosil-Santamaria, M., Picaza-Gorrochategui, M., \& Idoiaga-Mondragon, N. (2020). Niveles de estrés, ansiedad y depresión en la primera fase del brote del COVID19 en una muestra recogida en el norte de España. Cadernos de Saúde Pública, 36(4). https://doi.org/10.1590/0102-311X00054020

Peitl, V., Zatezalo, V. G., \& Karlović, D. (2020). Mental Health Issues and Psychological Crisis Interventions During the COVID-19 Pandemic and Earthquakes in Croatia. Archives of Psychiatry Research, 56, 193-198. https://doi.org/10.20471/dec.2020.56.02.07 
Pepperdine, E., Lomax, C., \& Freeston, M. H. (2018). Disentangling intolerance of uncertainty and threat appraisal in everyday situations. Journal of Anxiety Disorders, 57, 31-38. https://doi.org/10.1016/j.janxdis.2018.04.002

Rodríguez de Behrends, M., \& Brenlla, M. E. (2015). Adaptación para Buenos Aires de la Escala de Intolerancia a la Incertidumbre. Interdisciplinaria, 32(2), 261-274. https://www.redalyc.org/pdf/180/18043528004.pdf

Sanz, J., \& Vázquez, C. (1998). Fiabilidad, validez y datos normativos del Inventario para la Depresión de Beck. Psicothema, 10(2), 303-318. https://www.redalyc.org/pdf/727/72710207.pdf

Sanz, J., \& Vázquez, C. (2011). Adaptación española del Inventario para Depresión de Beck-II (BDI-II). Manual. Pearson.

Sanz, J., García-Vera, M. P., Espinosa, R., Fortún, M., \& Vázquez, C. (2005). Adaptación española del Inventario para la Depresión de Beck-II (BDI-II): 3. Propiedades psicométricas en pacientes con trastornos psicológicos. Clínica y Salud, 16(2), 121-142. https://www.redalyc.org/pdf/1806/180616104001.pdf

Sanz, J., Perdigón, A. L., \& Vázquez, C. (2003). Adaptación española del Inventario para la Depresión de Beck-II (BDI-II): 2. Propiedades psicométricas en población general. Clínica y Salud, 14(3), 249-280. https://www.redalyc.org/pdf/1806/180617972001.pdf

Satici, B., Saricali, M., Satici, A. S., \& Griffiths, M. D. (2020). Intolerance of Uncertainty and Mental Wellbeing : Serial Mediation by Rumination and Fear of COVID-19. International Journal of Mental Health and Addiction. https://doi.org/10.1007/s11469-020-00305-0

Sedgwick, P. (2012). Log transformation of data. BMJ (Online), 345, e6727. https://doi.org/10.1136/bmj.e6727

Sexton, K. A., \& Dugas, M. J. (2009). Defining distinct negative beliefs about uncertainty: Validating the factor structure of the Intolerance of Uncertainty Scale. Psychological Assessment, 21(2), 176-186. https://doi.org/10.1037/a0015827

Sim, K., \& Chua, H. C. (2004). The psychological impact of SARS: A matter of heart and mind. Canadian Medical Association Journal, 170(5), 811-812. http://doi.org/10.1503/cmaj.1032003

Spielberger, C. D., Gorsuch, R. L., Lushene, R. E. (1970) Manual for the State-Trait Anxiety Inventory. Consulting Psychologists Press.

Spielberger, C. D., Gorsuch, R. L., Lushene, R. E., \& Cubero, N. S. (1999). STAI: Cuestionario de ansiedad estado-rasgo. TEA Ediciones.

Taha, S., Matheson, K., Cronin, T., \& Anisman, H. (2014). Intolerance of uncertainty, appraisals, coping, and anxiety: The case of the 2009 H 1 N 1 pandemic. British Journal of Health Psychology, 19(3), 592-605. https://doi.org/10.1111/bjhp.12058

Timmerman, M. E., \& Lorenzo-Seva, U. (2011). Dimensionality assessment of ordered polytomous items with parallel analysis. Psychological Methods, 16(2), 209-220. https://doi.org/10.1037/a0023353

Tolin, D. F., Abramowitz, J. S., Brigidi, B. D., \& Foa, E. B. (2003). Intolerance of uncertainty in obsessive-compulsive disorder. Journal of Anxiety Disorders, 17(2), 233-242. https://doi.org/10.1016/S0887-6185(02)00182-2

Toro, R. A., Avendaño-Prieto, B. L., \& Vargas, N. (2019). Transdiagnostic model of anxiety and depression according to the relationship with affect, intolerance of uncertainly, and anxiety sensitivity. Revista CES Psicología, 13(1), 140-152. https://doi.org/10.21615/cesp.13.1.9 
Toro, R., Alzate, L., Santana, L., \& Ramírez, I. (2018). Afecto negativo como mediador entre intolerancia a la incertidumbre, ansiedad y depresión. Ansiedad y Estrés, 24(2-3), 112-118. https://doi.org/10.1016/j.anyes.2018.09.001

Van de Velde, S., Bracke, P., \& Levecque, K. (2010). Gender differences in depression in 23 European countries. Cross-national variation in the gender gap in depression. Social Science \& Medicine, 71(2), 305-313. https://doi.org/10.1016/j.socscimed.2010.03.035

Wieland, A., Durach, C. F., Kembro, J., \& Treiblmaier, H. (2017). Statistical and judgmental criteria for scale purification. Supply Chain Management, 22(4), 321-328. https://doi.org/10.1108/SCM-07-2016-0230

World Health Organization (2014). Health for the world's adolescents: A second chance in the second decade. http://public.tableausoftware.com/profile/digitalteam\#!/vizhome/shared/3JW3RBSZ3

Yook, K., Kim, K. H., Suh, S. Y., \& Lee, K. S. (2010). Intolerance of uncertainty, worry, and rumination in major depressive disorder and generalized anxiety disorder. Journal of Anxiety Disorders, 24(6), 623-628.https://doi.org/10.1016/j.janxdis.2010.04.003

Zandifar, A., \& Badrfam, R. (2020). Iranian mental health during the COVID-19 epidemic What. Asian Journal of Psychiatry, 51, 101990. https://doi.org/10.1016/j.ajp.2020.101990

Zvolensky, M. J., Leyro, T. M., Bernstein, A., \& Vujanovic, A. A. (2011). Historical Perspectives, Theory, and Measurement of Distress Tolerance. In M. J. Zvolensky, A. Bernstein, \& A. A. Vujanovic (Eds.), Distress Tolerance (pp. 3-27). The Guilford Press.

Zvolensky, M. J., Vujanovic, A. A., Bernstein, A., \& Leyro, T. M. (2010). Distress tolerance: Theory, measurement, and relations to psychopathology. Current Directions in Psychological Science, 19(6), 406-410. https://doi.org/10.1177/0963721410388642 